\title{
Toward a better understanding of the subtropical Atlantic Forest in the state of Santa Catarina, Brazil: tree sampling accuracy, species richness and frequency of rare species
}

\author{
Vanessa Leite Rezende ${ }^{1}$, Pedro V. Eisenlohr ${ }^{1,3}$, André Luís de Gasper ${ }^{1,2}$,
} Alexander Christian Vibrans ${ }^{2}$ and Ary Teixeira de Oliveira-Filho ${ }^{1}$

Received: April 27, 2013. Accepted: March 18, 2014.

\begin{abstract}
Accurate knowledge of floristic composition is crucial when planning and designing research projects and public policies. In this study, our goal was to assess tree sampling accuracy and to identify sites with higher concentrations of rare tree species, as well as those with the highest tree species richness, in the state of Santa Catarina, Brazil. We determined sampling accuracy using the first-order jackknife and Chao 2 estimators, calculated the number of rare species (singletons and doubletons) and applied sampled-based rarefaction. We found that sample accuracy (estimated vs. observed values) was over $90 \%$ for the state as a whole, the best estimates having been obtained for the areas of rain forest (first-order jackknife: 91\%; Chao 2: 95\%). Of the tree species identified, $16.6 \%$ were considered rare in the state and only $4 \%$ were found in all forest types. Among the various forest types, semideciduous forests showed the highest proportions of rare tree species. Tree species richness was highest in the rain forests and lowest in the dwarf cloud forests. Our results make an important contribution to the conservation of tree species within one of the "hottest" biodiversity hotspots in the world.
\end{abstract}

Key words: Chao 2, rainforest, first-order jackknife, rare species, semideciduous forest

\section{Introduction}

Although Brazil is one of the most biodiverse countries of the world, its vegetation has not been well sampled. Various authors have demonstrated that vegetation sampling is insufficient in Brazil, as well as that records of species occurrence in the country are unequally distributed (Giulietti et al. 2005; Sobral \& Stehmann 2009; Forzza et al. 2012). For example, of the 696 new records of angiosperms added to the List of Species of the Brazilian Flora between 2010 and 2012 (Lista de Espécies da Flora do Brasil 2012), 237 were for the state of Santa Catarina, compared with only 188 for the entire Amazon region, despite the vast expanse of natural vegetation within the latter. This suggests that the estimation of species richness is biased by the greater concentration of research centers and universities in areas that are more developed, resulting in a tendency to collect plant specimens repeatedly from sites previously recognized as having the highest levels of species richness (Ponder et al. 2001; Schatz 2002; Hopkins 2007; Sobral \& Stehmann 2009). That limits our knowledge of the true species richness distribution (Sastre \& Lobo 2009), the delimitation of centers of endemism (Ponder et al. 2001) and the decisionmaking process related to the designation of priority areas for conservation (Grand et al. 2007).

The Atlantic Forest sensu lato (Joly et al. 1999) is considered one of the major global hotspots for biological conservation purposes (Myers et al. 2000; Ribeiro et al. 2011). Among the various Atlantic Forest subtypes, the rain forest is the richest vegetation formation in terms of rare species and overall species number (Martins 1991; Scudeller et al. 2001; Oliveira-Filho \& Fontes 2000; Caiafa \& Martins 2010; Vibrans et al. 2010). The fact that the rain forest harbors so many threatened tree species-especially in its southern section-can be explained by its high numbers of rare species, together with an abundance of species considered to have a restricted habitat (stenoecious species) and reduced local abundance, or even a combination of these factors (Caiafa \& Martins 2010). Rain forests occur in climates with warm temperatures and no dry season (Colombo \& Joly 2010), which favors the establishment of a larger set of species than in semideciduous forests (Oliveira-Filho \& Fontes 2000). The fact that the level of environmental

\footnotetext{
${ }^{1}$ Universidade Federal de Minas Gerais, Instituto de Ciências Biológicas, Departamento de Botânica, 30161-970 Belo Horizonte, MG, Brazil

${ }^{2}$ Universidade Regional de Blumenau, Inventário Florístico Florestal de Santa Catarina, Rua São Paulo, 3250, Itoupava Seca, 89030-000 Blumenau, SC, Brazil

${ }^{3}$ Author for correspondence: pedrov.eisenlohr@gmail.com
} 
Toward a better understanding of the subtropical Atlantic Forest in the state of Santa Catarina, Brazil:

tree sampling accuracy, tree species richness and frequency of rare tree species

heterogeneity is higher in rain forests than in other forest types (Leitão-Filho 1994) also contributes to the high species richness in the former.

During the second half of the twentieth century, the state of Santa Catarina suffered a drastic reduction in forest cover, and there is still constant pressure associated with economic activities such as agriculture and extensive livestock farming (Vibrans et al. 2010; 2011). When only trees with a height of at least $10 \mathrm{~m}$ and a basal area of at least $10 \mathrm{~m}^{2} \cdot \mathrm{ha}^{-1}$ are considered, the total forest cover in the state is estimated at 29\% (Vibrans et al. 2013), with differences among forest types: $16 \%$ for semideciduous forest; $24 \%$ for mixed (broadleaf and needleleaf) forest, also known as Araucaria forest; and $40 \%$ for rain forest. In addition, recent estimates state that there are 500,000 ha of forest plantations, mainly Pinus spp., equivalent to $5 \%$ of the total area of the state (Vibrans et al. 2010). As has been demonstrated by various authors (Sampaio \& Guarino 2007; Aragão et al. 2008; Caiafa \& Martins 2010; Peres et al. 2010; Zafra-Calvo et al. 2010), human activities can reduce populations of many species or even cause extinction. Therefore, species with restricted distribution are especially vulnerable if their geographic range is limited or they have special habitat needs (Primack \& Rodrigues 2001). Identifying regions with a high number of rare species-as well as with a high level of overall species richness-is a major requirement of good conservation practice (Primack \& Rodrigues 2001; Caiafa et al. 2009; Caiafa \& Martins 2010).

To assess the conservation status of native forests, the state of Santa Catarina conducted the Inventário Florístico Florestal de Santa Catarina (IFFSC, Floristic Inventory of Forests within the State of Santa Catarina) between 2007 and 2010, using a systematic sampling method to produce detailed and reliable data on community structure and floristic composition (Vibrans et al. 2010). The IFFSC included all forest types found in the state: coastal dwarf forest, rain forest, dwarf cloud forest, mixed forest and semideciduous forest (sensu Oliveira-Filho 2009). The sampling plots, in the form of a cluster of four crosswise $1000 \mathrm{~m}^{2}$ subplots (20 $\times 50 \mathrm{~m}$ ), were located in forest vegetation at the intersections of a $10 \times 10 \mathrm{~km}$ grid, except in the semideciduous forest, where a $5 \times 5 \mathrm{~km}$ grid was employed; this ensured a sufficient number of sample plots to allow the assessment of tree and shrub species, given that, among the five forest types found in Santa Catarina, the semideciduous forest is the most reduced and fragmented (Vibrans et al. 2010). From the 48,427 records of trees and shrubs provided by the IFFSC, broad patterns of species distribution and richness can be identified (Vibrans et al. 2010). Detecting such patterns by standardized sampling reduces the drawbacks associated with an insufficient sample size, especially in tropical areas, for which biodiversity data are often scarce, biased and of low quality (Hortal et al. 2007).

The objective of the present study was to use IFFSC data, together with data from other sources, in order to determine the accuracy of tree sampling in the various forest types within the state of Santa Catarina. We also attempted to identify the areas of the state in which the proportions of rare species were greatest and the levels of species richness were highest. Given that the rain forest subtype of Atlantic Forest has fewer environmental constraints, a larger forest cover and greater habitat heterogeneity than do other Atlantic Forest subtypes, we expected the level of species richness to be highest in the areas of rain forest occurring within the state. We also expected that such areas would have the greatest proportions of rare species.

\section{Material and Methods}

\section{Study area}

The state of Santa Catarina is located in southern Brazil (255' $41^{\prime \prime}-29^{\circ} 23^{\prime} 55^{\prime \prime}$ '; $\left.48^{\circ} 19^{\prime} 37^{\prime \prime}-53^{\circ} 50^{\prime} 00^{\prime \prime} \mathrm{W}\right)$. The relief consists of a Quaternary coastal plain, a set of coastal ranges with an abundance of crystals in eastern Santa Catarina, the Gondwana Plateau and a basalt plateau (Santa Catarina 1986). Approximately $70 \%$ of the state of Santa Catarina is at least $300 \mathrm{~m}$ a.s.l., the relief being mostly composed of a basalt plateau connecting with the Serra Geral mountain range (Andrade et al. 1999). The climate in the southern plateau region is quite humid and mesothermal (Cfb), whereas that along the Atlantic coastal range is super humid subtropical, with high temperatures (Cfa) (Klein 1984). In Santa Catarina, the average monthly rainfall ranges from $1100 \mathrm{~mm}$ to $2900 \mathrm{~mm}$, with no excesses or shortages of water during the year (Pandolfo et al. 2002). We show the elevation and climate maps in Fig. 1.

\section{Database}

We obtained the species occurrence data from the TreeAtlan 2.0 database (Oliveira-Filho 2010), which is compiled from the literature and herbarium specimens. The database contains records of tree species occurrence, geographic location, type of vegetation and environmental data. For the state of Santa Catarina, the database was improved by the incorporation of data from the IFFSC, which employs a systematic and non-biased sampling method for all forest types (Vibrans et al. 2010). The data set for the present study was related to a total of 175 sites, each with a radius of $5 \mathrm{~km}$, across five forest types (see details of the TreeAtlan protocol in Oliveira-Filho 2010 and Eisenlohr \& Oliveira-Filho [in press]), distributed throughout the state (Fig. 2). We defined the forest types on the basis of the nomenclature proposed by Oliveira-Filho (2009): coastal woodland, also known as restinga or sandy forest; rain forest, or floresta ombrófila densa in a more regional (Brazil) context (IBGE 2012); dwarf cloud forest, or floresta nebular; mixed (broadleaf and needleleaf) forest, or Araucaria forest (hereafter, mixed forest); and semideciduous forest. 


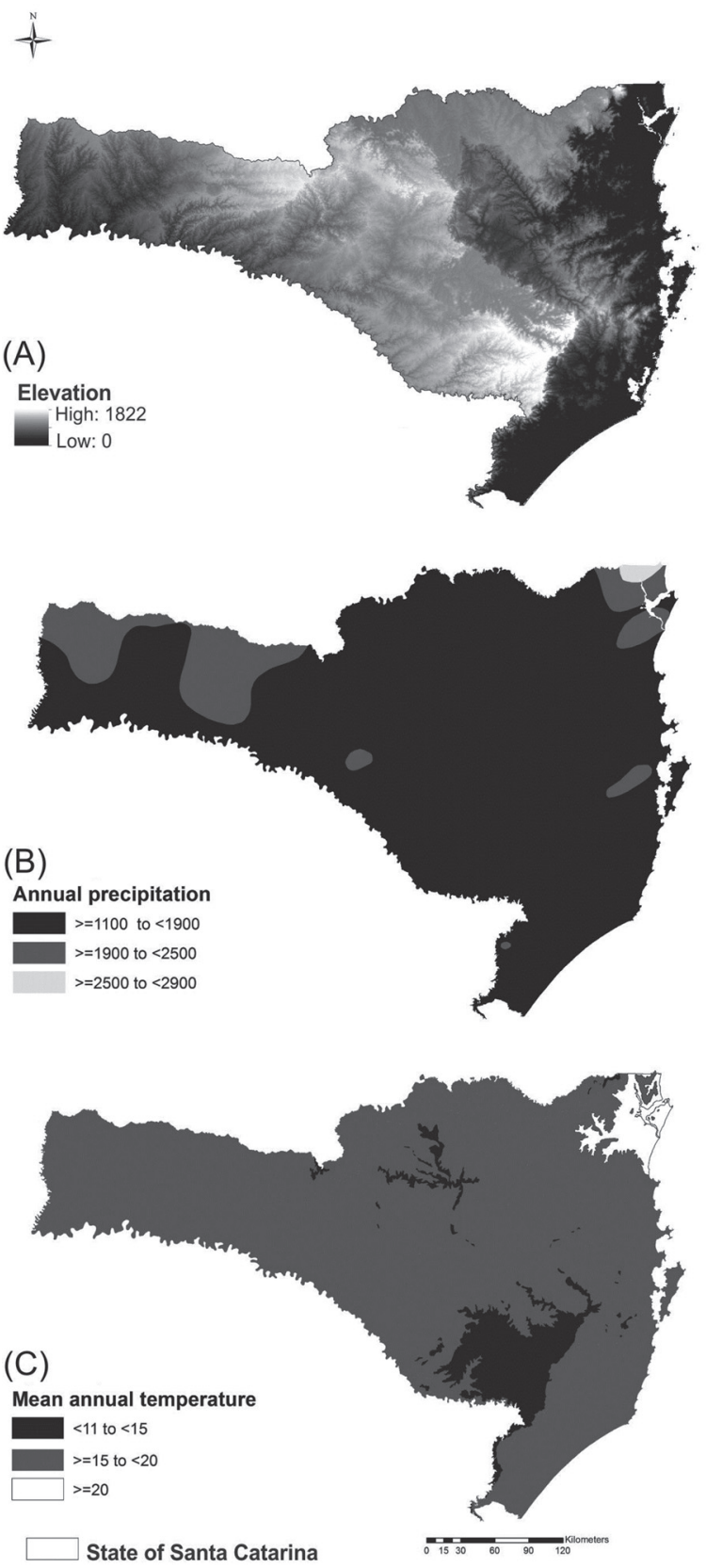

Figure 1. Elevation (A), annual precipitation (B) and mean annual temperature (C) for the subtropical Atlantic Forest in the state of Santa Catarina, Brazil.

\section{Numerical analyses}

We examined the sampling accuracy by obtaining estimates of species richness, using the first-order jackknife and Chao 2 estimators in the program EstimateS, version 8.2.0 (Colwell 2009). The first-order jackknife estimator predicts the number of species based on the frequency of species found in one area, projecting the total number of species on the basis of the heterogeneity of the sample (Chiarucci et al. 2003). The Chao 2 estimator is based on the concept of statistical sampling coverage, using the number of species with low frequency to estimate the number of species not included in the sample (Colwell \& Coddington 1994; Chazdon et al. 1998), thus generating a consistent estimate of the minimum number of species (Longino et al. 2002). We decided to use both estimators because each employs different concepts, as noted above (for a thorough review, see Magurran 2004 and references therein), which helped us generate a complementary and more reliable approach.

We examined variations in the proportions of rare species and total species richness, in order to contribute additional data in order to inform decisions regarding conservation priorities in Santa Catarina. In this manuscript, we define rare species as singletons or doubletons, meaning species that occur in only one or two sample units, respectively (Magurran 2004). We analyzed the percentage of rare species (singletons and doubletons) in relation to the total number of species found both in the state as a whole and within each forest type.

We prepared a map of the observed species richness using the programs ArcGis, version 10 (ESRI 2010) and DivaGis, version 7.4 (Hijmans et al. 2005), calculating the mean and median species richness for each forest type. To check a possible influence of the number of sampling sites on the estimated richness, we performed simple linear regression using an ordinary least squares (OLS) model. Because the OLS model was significant $\left(R_{\text {adjusted }}^{2}=0.894\right.$; $p=0.02$ ), we compared species richness between the forest types by applying sample-based rarefaction (Gotelli \& Colweell 2001) in the program ECOSIM, version 7.72 (Gotelli \& Entsminger 2004). For a better view of the rarefaction process, we constructed a graph in the program R, version 2.15.3 (The R Foundation for Statistical Computing 2012), using the ggplot2 package, version 0.9.3.1 (Wickham \& Chang 2013).

\section{Results}

At 175 sites within the state of Santa Catarina, we identified 23,559 individuals of 913 tree species, among 312 genera and 99 families (the distribution of species richness per site can be seen in Fig. 3). Of the 913 species, only 38 (4\%) occurred in all forest types. The family with the highest level of species richness was Myrtaceae, which accounted for $19.7 \%$ of the species, followed by Fabaceae (at 9.8\%) and Lauraceae (at 6.0\%).

When analyzing the increase in species richness-observed and estimated (by first-order jackknife and Chao 2) - we found that the curve seemed to stabilize (Fig. 4). However, that does not necessarily mean that the sample size was sufficient (Schilling \& Batista 2008). The sample size can be considered sufficient-and therefore the sampling can be considered accurate-because we found the concordance between the observed and estimated species counts to be $\approx 91 \%$ when the first-order jackknife estimator was used (913 vs. 1002.49 species; Tab. 1 ) and $\approx 94 \%$ when the Chao 2 estimator was used (913 vs. 976.21 species; 


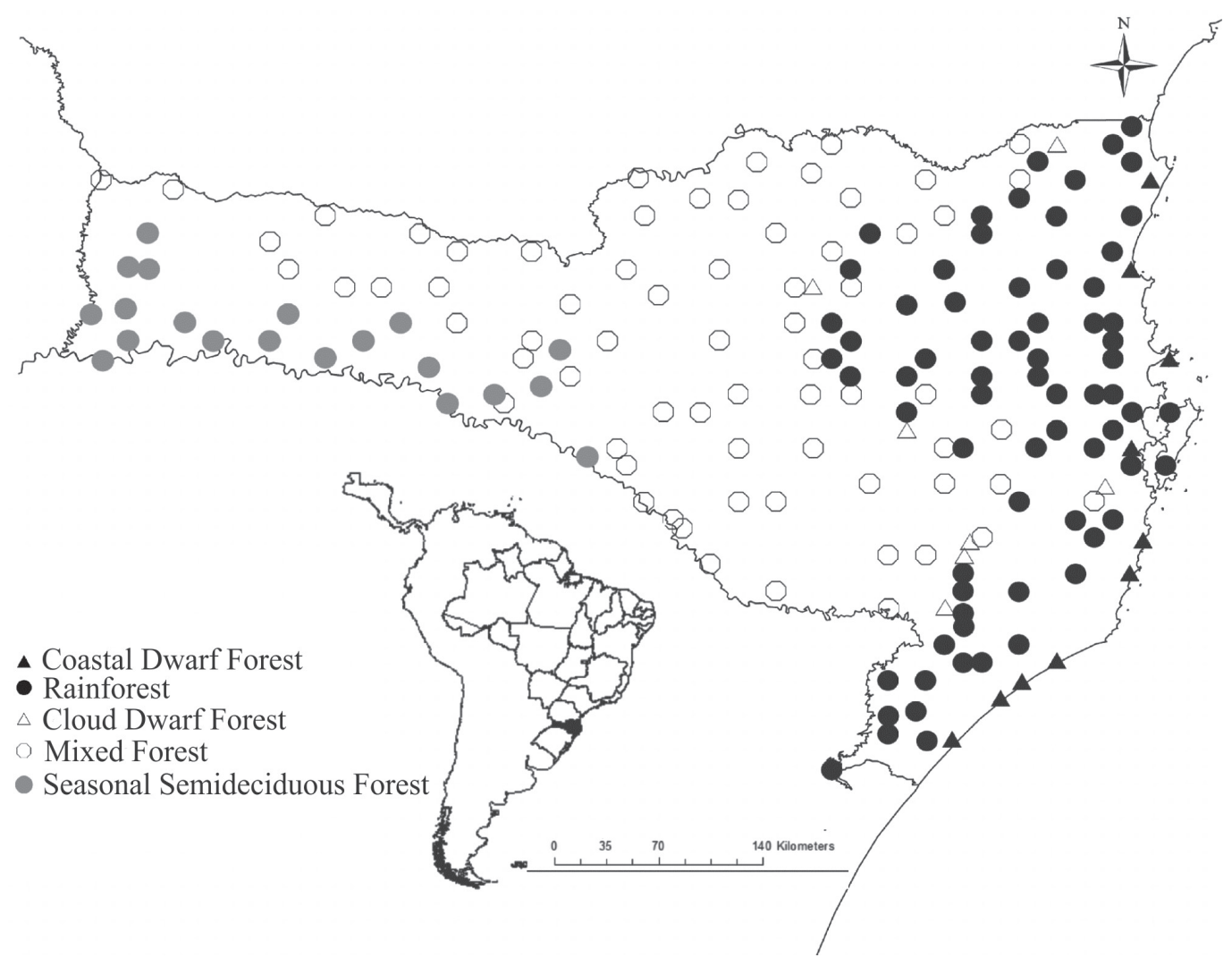

Figure 2. Distribution of the study sites among the forest types in the state of Santa Catarina, Brazil.

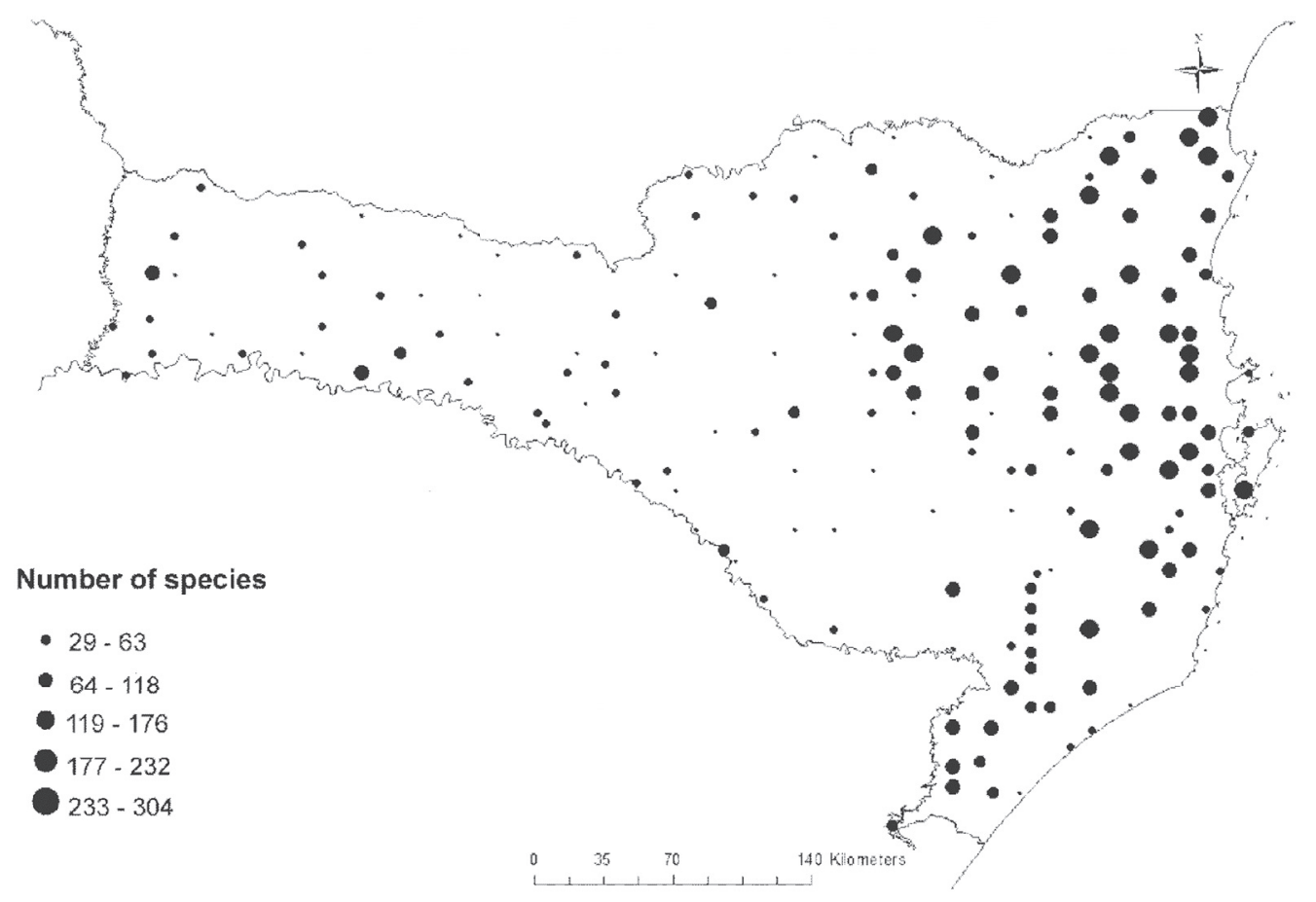

Figure 3. Range of the number of species per sampled site in the state of Santa Catarina, Brazil. 


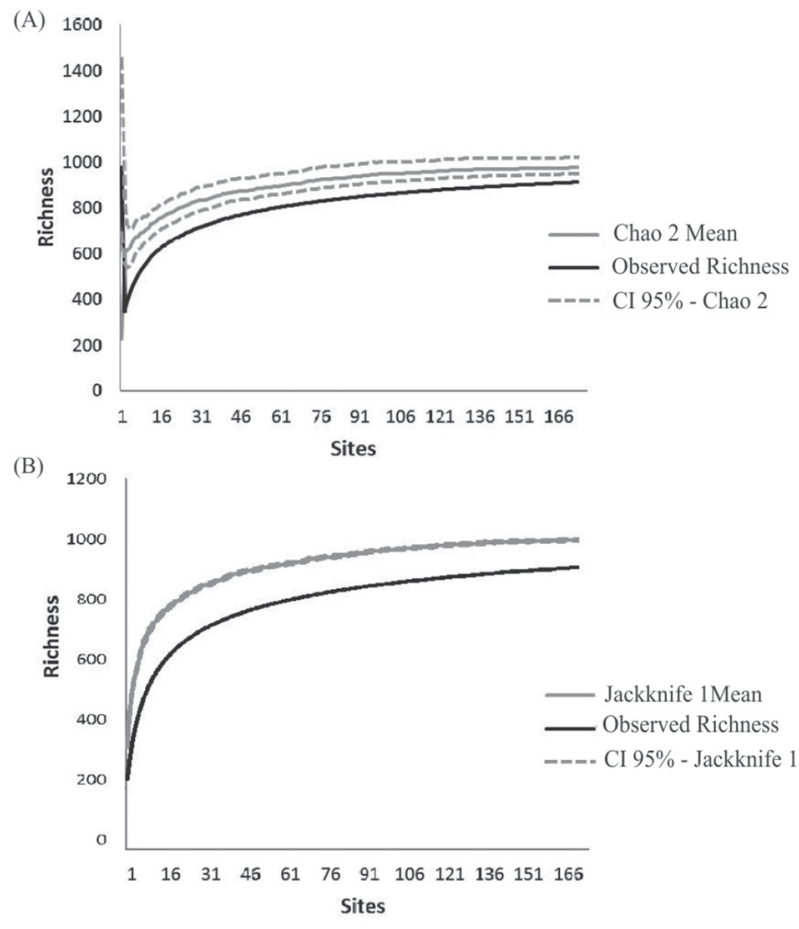

Figure 4. Species accumulation curves (observed richness) and estimation of species richness according to the first-order jackknife (A) and Chao 2 (B) estimators for the state of Santa Catarina, Brazil.

Tab. 1). In addition, the degree of that concordance was high for all forest types (Tab. 1, Fig. 5 and 6), indicating high sampling accuracy in Santa Catarina. As shown in Tab. 1, the accuracy (concordance with the observed richness) was highest for the areas of rain forest $(\approx 91 \%$ and $\approx 95 \%$ for the first-order jackknife and Chao 2 estimators, respectively) and lowest for the areas of semideciduous forest $(\approx 78 \%$ for the first-order jackknife estimator) and mixed forest $(\approx 79 \%$ for the Chao 2 estimator). Nevertheless, mixed forest was the second richest forest type in the state (Tab. 1). At the beginning of the cumulative species curves for the dwarf forest category (including dwarf cloud forests and restingas), for which the number of sites was relatively small (seven for dwarf cloud forest and 10 for restinga), there was a different response, values for the first sites sampled being higher (Fig. 6). This occurred because the Chao 2 estimator is based on the number of singletons and tends to overestimate the species richness of an area where there are few sites and large number of singletons (Colwell \& Coddington 1994; Santos 2006).

Among the 913 tree species identified in the state of Santa Catarina, there were 90 singletons $(\approx 10 \%)$ and 62 doubletons $(\approx 7 \%)$, rare species therefore accounting for $\approx 17 \%$ of the overall species richness. When the forest types were analyzed separately, the proportion of rare species (singletons plus doubletons) was highest for semideciduous forest $(\approx 48 \%)$, followed by restinga $(\approx 47 \%)$ and dwarf cloud forest $(\approx 41 \%)$. The proportion of singletons was highest for restinga and semideciduous forest $(\approx 31 \%$ and $\approx 30 \%$, respectively), as was that of doubletons $(\approx 17 \%$ and $\approx 18 \%$, respectively), whereas both were low $(\approx 9 \%)$ for rain forests.

The values for tree species richness-observed, estimated, mean and median-were highest for rain forest (Tab. 1). Even when the effect of sample size was considered in the rarefaction procedure, the rain forest areas maintained that distinction, at all levels of comparison (Fig. 7). Nevertheless, some species-rich sites were also found in other parts of the state, such as the western region (Fig. 3), where semideciduous forest predominates.

\section{Discussion}

The accuracy of measures of species richness is quantified by determining how close the values obtained by such measures are to the "true" values (Stuart \& Ord 1991; Walther \& Moore 2005). In the present study, we considering the "true" values to be those estimated by two non-parametric estimators (first-order jackknife and Chao 2). We could expect that the sampling accuracy would be high, because the IFFSC employs a systematic and non-biased sampling

Table 1. Parameters of species richness for forest types in the state of Santa Catarina, Brazil.

\begin{tabular}{|c|c|c|c|c|c|c|c|c|c|}
\hline \multirow{3}{*}{ Forest Types } & \multirow{3}{*}{ S } & \multicolumn{2}{|c|}{ 1st-order Jackknife } & \multicolumn{2}{|c|}{ Chao 2} & \multirow{3}{*}{$\mathrm{N}$ of sites } & \multirow{3}{*}{ Singletons } & \multirow{3}{*}{ Doubletons } & \multirow{2}{*}{$\begin{array}{l}\text { Species } \\
\text { richness }\end{array}$} \\
\hline & & Estimated & $\begin{array}{l}\text { Sampling } \\
\text { accuracy }^{*}\end{array}$ & Estimated & $\begin{array}{l}\text { Sampling } \\
\text { accuracy }^{*}\end{array}$ & & & & \\
\hline & & & $(\%)$ & & $(\%)$ & & & & Mean/Median \\
\hline Coastal woodland & 272 & 346.70 & 78.45 & 337.16 & 80.67 & 10 & 83 & 46 & $87 / 86$ \\
\hline Rain forest & 773 & 846.85 & 91.16 & 810.98 & 95.32 & 69 & 76 & 71 & $220 / 224$ \\
\hline Mixed forest & 477 & 584.40 & 81.62 & 605.88 & 78.73 & 68 & 109 & 44 & $68 / 74$ \\
\hline Dwarf cloud forest & 257 & 301.14 & 80.36 & 294.92 & 87.14 & 7 & 69 & 37 & $110 / 116$ \\
\hline Semideciduous forest & 316 & 406.25 & 77.78 & 389.13 & 81.21 & 20 & 95 & 57 & $87 / 76$ \\
\hline Total & 913 & 1002.49 & 91.07 & 976.21 & 93.51 & 175 & 90 & 62 & $134 / 108$ \\
\hline
\end{tabular}

S - number of observed species; Singletons - species occurring only one site; Doubletons - species occurring at only two sites.

${ }^{*}$ Proportion of species observed in relation to the estimated value. 
(A)

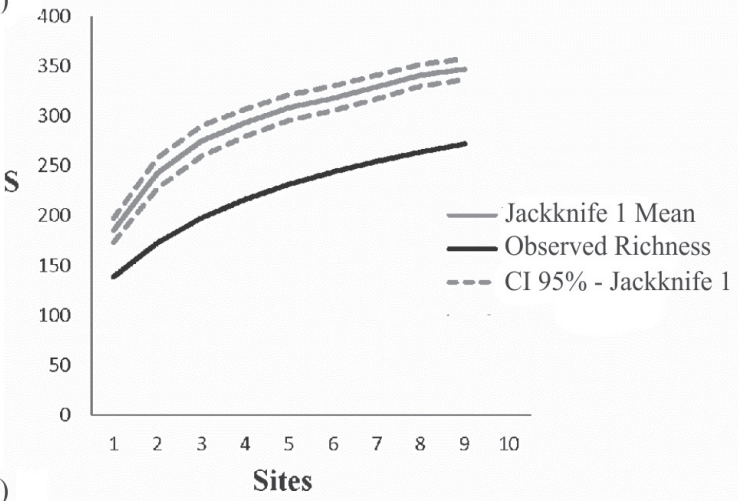

(C)

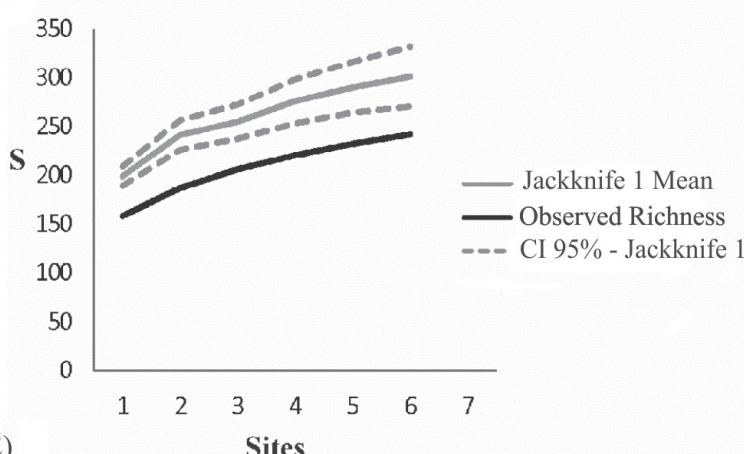

(E)

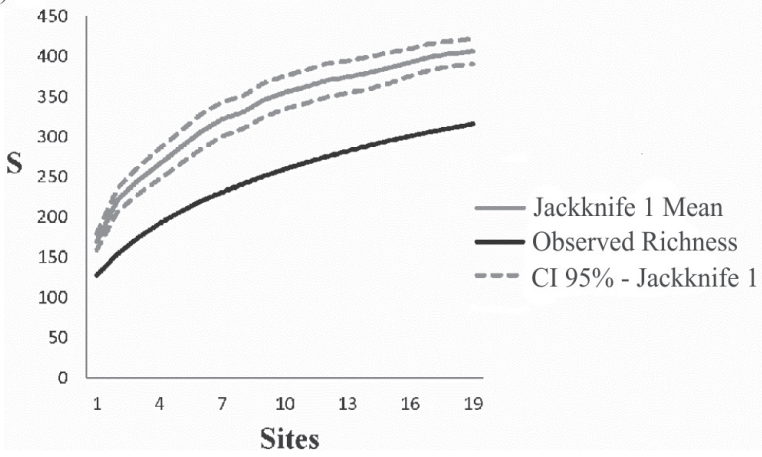

(B)

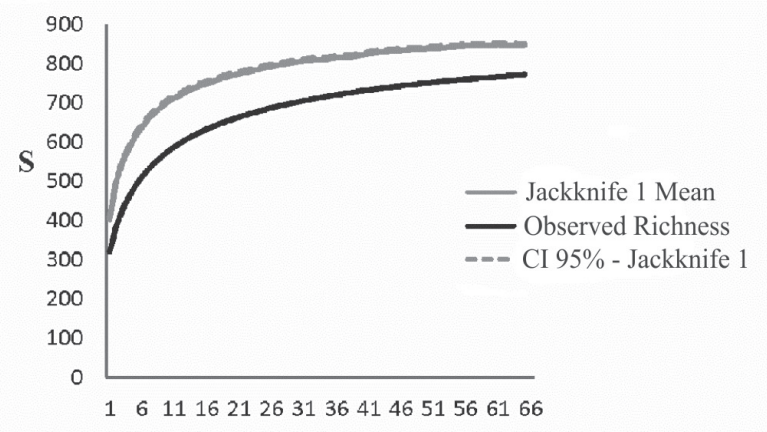

(D)

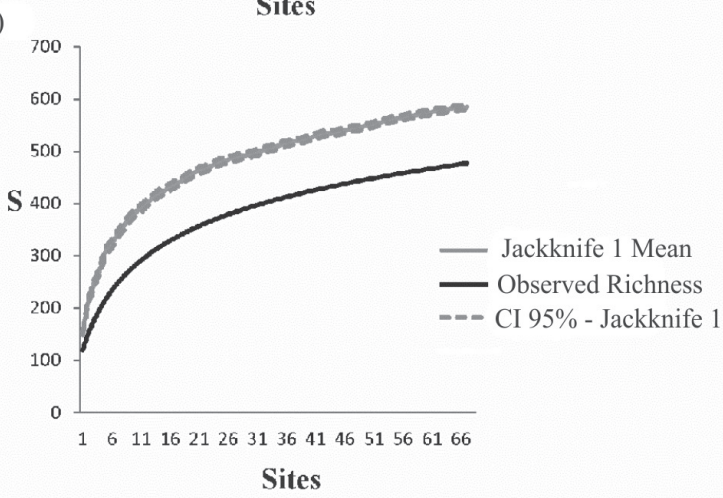

Figure 5. Species accumulation curves (observed richness) and estimated species richness according to the first-order jackknife estimator for the five forest types of the state of Santa Catarina, Brazil. (A) restinga (coastal woodland), (B) rain forest, (C) dwarf cloud forest, (D) mixed forest and (E) semideciduous forest. $\mathrm{S}$ - species richness.

method for all forest types. As previously mentioned, sampling accuracy was high in Santa Catarina and the level of species richness was higher for rain forest than for the other four forest types evaluated in the state. However, contrary to what would be expected, the proportion of rare species was highest for semideciduous forest, which has been shown to account for only $16.1 \%$ of the forest cover in Santa Catarina, rather than for rain forest, which is less fragmented than is the semideciduous forest and has been shown to account for $40.5 \%$ of the forest cover in the state (Vibrans et al. 2013).

Differences between the observed and estimated tree species richness, even for areas with the lowest richness (semideciduous and mixed forests), have indicated that sampling accuracy is high in the state of Santa Catarina (JiménezValverde \& Hortal 2003). In fact, using rarefaction curves of the IFFSC data set, Vibrans et al. (2012) showed that with only half of the sampling effort, $83 \%$ of all species were found in rain forests and semideciduous forests, whereas $85 \%$ of all species were found in mixed forests. Considering the curves for each sample site, those authors observed that (again at only half of the sampling effort) the mean proportions of the total number of species detected at each site were $68 \%$ (for rain forest and semideciduous forest) and $72 \%$ (for mixed forest). In that same study, the authors reported stabilization of the current mean species number and variance of the species number within each sample site (computed from subplot data), which are equal indicators of sampling reliability.

In the present study, we found semideciduous forest to be the forest type with the highest number of rare species (singletons and doubletons). This can be explained by factors 

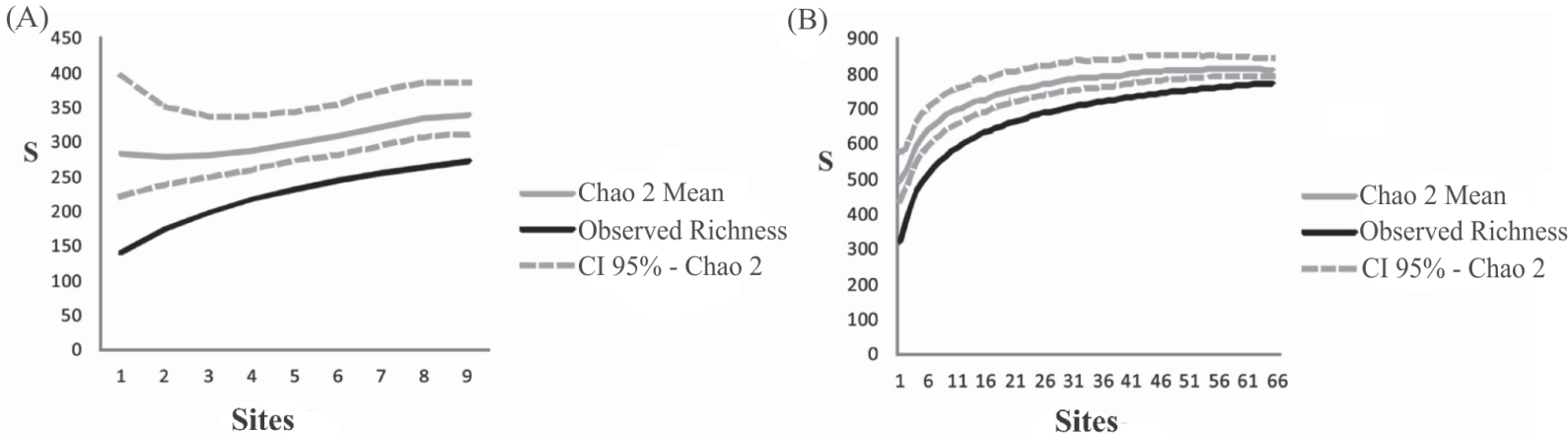

(C)

(D)
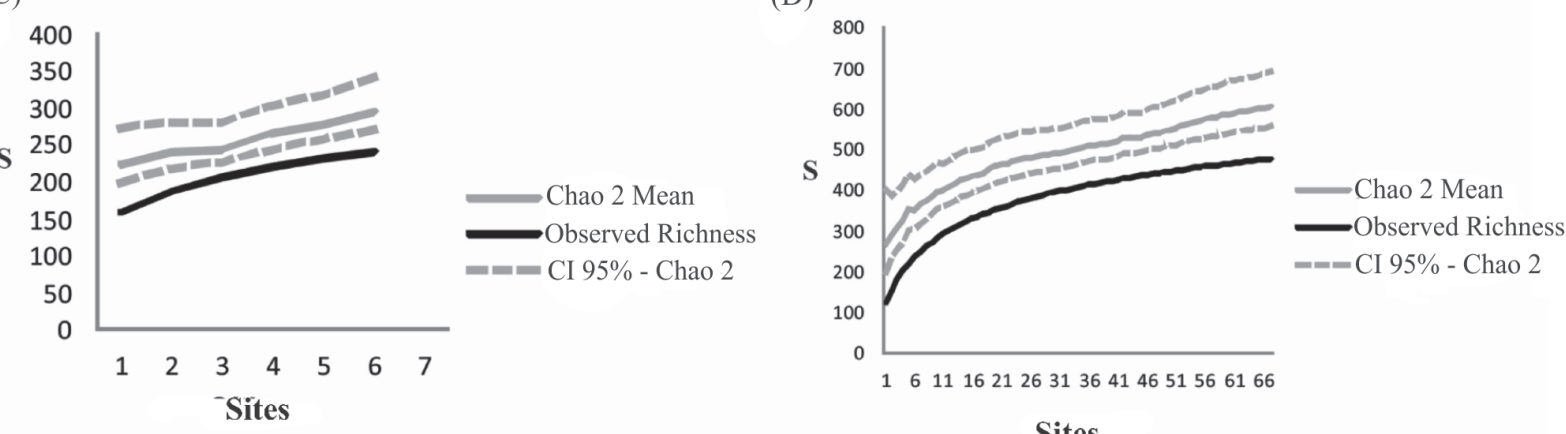

Sites

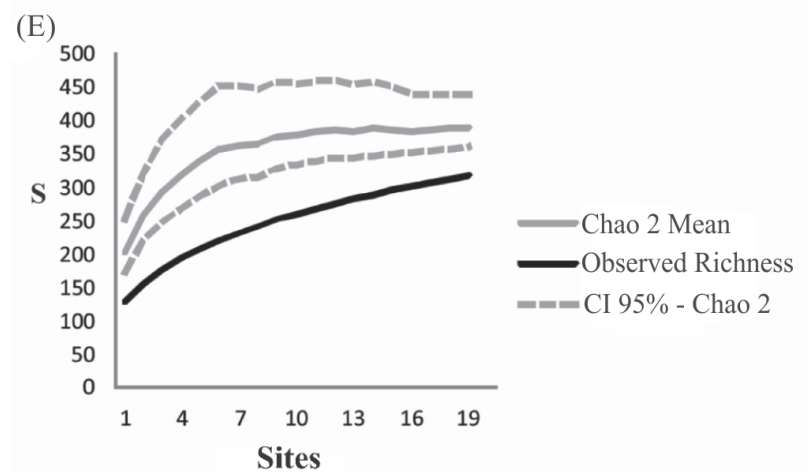

Figure 6. Species accumulation curves (observed richness) and estimated species richness according to Chao 2 estimator for the five forest types of the state of Santa Catarina, Brazil. (A) restinga, (B) rain forest, (C) dwarf cloud forest, (D) mixed forest, (E) semideciduous forest.

$\mathrm{S}$ - species richness.

such as adaptation to specific climatic factors and the distance from the ocean. The restriction of a species to one forest type or geographic region might be attributable to ecophysiological adaptations that allow its survival in a particular region or to disturbances in its range of distribution, whereby a previously abundant species becomes rare (Harrison et al. 2008). The high number of exclusive species observed in our study might also be associated with a distinct migration of the flora that constitutes the semideciduous forests (Leite 2002). Semideciduous forests are composed of a variety of habitats (Leite 2002); therefore, the species that occur there do not occur to a large extent.

In southeastern Brazil (a tropical region), Caiafa \& Martins (2010) found that the proportion of rare species was greatest in areas of rain forest. However, the same was not found for the state of Santa Catarina (a subtropical region) in the present study. This difference is understandable if one considers the findings of Valente (2011), who showed that, among the subtypes of Atlantic Forest, the number of rare species was approximately 19 times higher in the rain forest subtype than in the subtropical forest subtype. In addition, the use of the TreeAtlan data base, which considers a radius of $5 \mathrm{~km}$, might lead to an overestimation of the number of singletons, because many different study areas can be found within that radius. Similarly, as noted by Rabinowitz et al. (1986), systematic sampling (such as that adopted in the IFFSC) can identify more rare species than can random surveys, in which species with a wide distribution are overrepresented and species with an intermediate distribution are underrepresented, whereas uncommon species are represented accurately. 


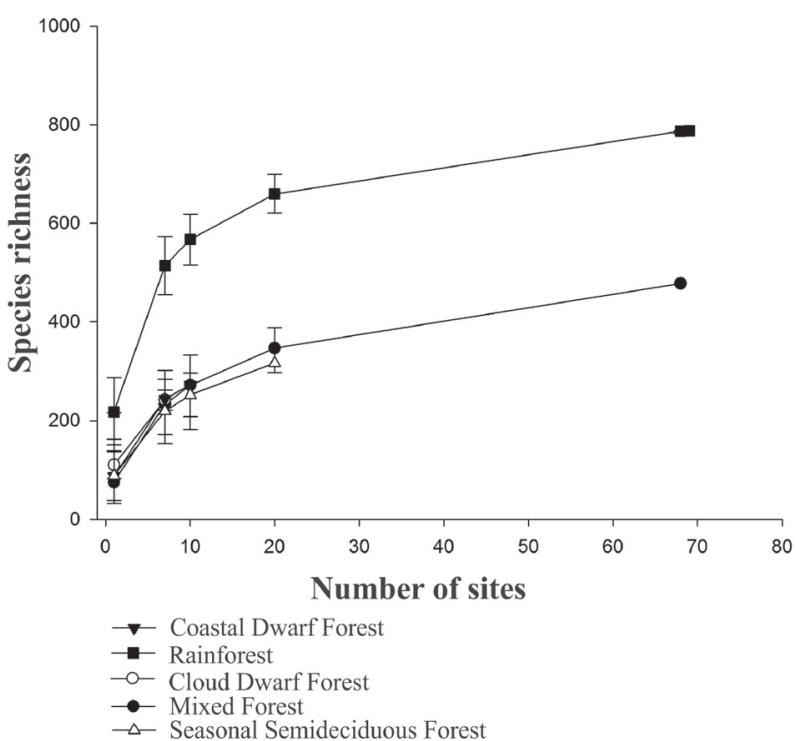

Figure 7. Sample-based rarefaction for the species richness of each forest type in the state of Santa Catarina, Brazil.

Bars indicate $95 \%$ CIs.

Considering the criteria of adequate sampling intensity and geographical coverage used in the IFFSC (Vibrans et al. 2010), the fact that species richness was highest in the rain forest might also be attributable to the fact that the rain forest accounts for the greatest proportion of forest cover in the state, as well as to the better conservation status of its remnants. In addition, various studies have indicated that the number of tree species per sample unit increases when the amount and frequency of rainfall are greater (as they are in rain forests) and decreases in proportion to the duration of the dry season (Gentry 1988; Nimer 1990; Clinebell II et al. 1995; Pitman et al. 2002; EPAGRI 2008). Together with shorter dry seasons, the high environmental heterogeneity generated by the hilly landscape (in the Serra Geral and Serra do Mar mountain ranges) might contribute to the high species richness in the areas of rain forest, where each elevation harbors a particular set of species (Martinelli 2007; Rocha \& Amorim 2012). The results of the rarefaction procedure, used in order to deal with the variation in sample size, confirmed that species richness was higher in the rain forest than in the other forest types.

The use of data from a systematic inventory, such as the IFFSC, and from updated databases, such as the TreeAtlan 2.0, allowed us to single out even less intensively studied regions as priority areas for conservation (Araujo \& Williams 2001; Giulietti et al. 2005; Grand et al. 2007; Sastre \& Lobo 2009). Gotelli \& Colwell (2001) stated that sampling biodiversity is a labor-intensive activity, and it is often not sufficient to detect all or even most of the species present in an area. Bebber et al. (2007) used a species-area curve to determine the rate at which the discovery of new taxa increases the curve and concluded that it is governed by the need to discover new species, as well as by the sampling intensity used for discovery and to publish descriptions of such species. Therefore, it is important to enhance our sampling and identification efforts, as well as to make the data available. We believe that our study contributes towards filling these gaps.

Although the number and proportion of rare species are expected to correlate with the number of sample sites, we believe that the analyses proposed here might be useful to provide additional contribution to the species distribution and biodiversity conservation for the state of Santa Catarina. To improve the characterization of the forest cover in Santa Catarina, future studies of tree species in the state should evaluate variables other than species richness, such as density and basal area. Such studies should also consider other life forms and the grasslands. The IFFSC and TreeAtlan databases proved to be extremely accurate, highlighting the great species richness in the rain forest and the importance of the semideciduous forest for species with restricted distribution.

Our results demonstrate that the dataset used in the analyses is a reliable source from which one can produce efficient descriptors of tree species diversity across the state of Santa Catarina. Hence, it is also a valuable tool for conservation initiatives in the subtropical portion of one of the "hottest" biodiversity hotspots in the world (Myers et al. 2000; Laurance 2009), and one that is shrinking (Ribeiro et al. 2011), the Atlantic Forest.

\section{Acknowledgments}

We are grateful to the anonymous referees for their valuable contributions to this manuscript. This study received financial support from the Coordenação de Aperfeiçoamento de Pessoal de Nivel Superior (CAPES, Office for the Advancement of Higher Education; master's scholarship to VLR), the Conselho Nacional de Desenvolvimento Científico e Tecnológico (CNPq, National Council for Scientific and Technological Development; research grant to PVE and ATOF) and the Fundação de Amparo à Pesquisa e Inovação de Santa Catarina (FAPESC, Foundation for the Support of Research and Innovation in the State of Santa Catarina; funding for the IFFSC).

\section{References}

Andrade, A.R.; Baldo, M.C. \& Nery, J.T. 1999. Variabilidade sazonal da precipitação pluviométrica de Santa Catarina. Acta Scientiarum 21 (4): 923-928.

Aragão, L.E.O.C.; Malhi, Y.; Barbier, N.; Lima, A.; Shimabukuro, Y.; Anderson, L. \& Saatchi, S. 2008. Interactions between rainfall, deforestation and fires during recent years in the Brazilian Amazonia. Philosophical transactions of the Royal Society of London, Series B, Biological Sciences 363: 1779-1785.

Araújo, M.B. \& Williams, P.H. 2001. The bias of complementarity hotspots toward marginal populations. Conservation Biology 15: 1710-1720.

Bebber, D.P.; Harris, S.A.; Gaston, K. J. \& Scotland, R.W. 2007. Ethnobotany and the first printed records of British flowering plants. Global Ecology and Biogeography 16: 103-108. 
Caiafa, A.N.; Martins, S.V.; Nunes, J.A. \& Eisenlohr, P.V. 2009. Espécies arbóreas raras. Pp. 245-261. In: Martins, S.V. (Ed.). Ecologia de Florestas Tropicais do Brasil. Viçosa, Editora UFV.

Caiafa, A.N. \& Martins, F.R. 2010. Forms of rarity of tree species in the southern Brazilian Atlantic rainforest. Biodiversity and Conservation 19(9): 2597-2618.

Chazdon, R.L.; Colwell, R.K.; Denslow, J.S. \& Guariguata, M.R. 1998. Statistical methods for estimating species richness of woody regeneration in primary and secondary rain forests of NE Costa Rica. Pp. 285-309. In: Dallmeier, F. \& Comiskey, J. (Eds.). Forest Biodiversity Research, Monitoring and Modeling: Conceptual Background and Old World Case Studies. Paris, Parthenon Publishing.

Chiarucci, A.; Enright, N.J.; Perry, G.L.W.; Miller, B.P. \& Lamont, B.B. 2003. Performance of nonparametric species richness estimators in a high diversity plant community. Diversity and Distributions 9: 283-295.

Clinebell II, R.R.; Phillips, O.L.; Gentry, A.H.; Stark, N. \& Zuuring, H. 1995. Prediction of neotropical tree and liana species richness from soil and climatic data. Biological Conservation 4: 56-90.

Colombo, A.F. \& Joly, C.A. 2010. Brazilian Atlantic Forest Lato Sensu: the most ancient Brazilian forest, and a biodiversity hotspot, is highly threatened by climate change. Brazilian Journal of Biology 70: 697-708

Colwell, R.K. \& Coddington, J.A. 1994. Estimating terrestrial biodiversity through extrapolation. Philosophical Transactions of the Royal Society (Series B) 345: 101-118.

Colwell, R.K. 2009. EstimateS: Statistical estimation of species richness and shared species from samples. Version 8. User's Guide and application. http://viceroy.eeb.uconn.edu/estimates (access on Dec 2012).

Eisenlohr, P.V. \& Oliveira-Filho, A.T. In press. Obtenção e estruturação de metadados para trabalhos fitogeográficos de síntese e o banco de dados TreeAtlan como estudo de caso. In: Eisenlohr, P.V.; Felfili, J.M.; Melo, M.M.R.F.; Andrade, L.A. \& Meira-Neto, J.A.A. (Eds.). Fitossociologia no Brasil: Métodos e Estudos de Casos. Vol.2. Viçosa, Editora UFV.

EPAGRI. 2008. Atlas climatológico do Estado de Santa Catarina. http:// ciram.epagri.rct-sc.br/ (access on Jan 2012).

ESRI. 2010. ArcGis Desktop: Release 10. Redlands, Environmental Systems Research Institute.

Forzza, R.C.; Baumgratz, J.F.A.; Bicudo, C.E.M.; Canhos, D.A.; Carvalho Jr., A.A.; Coelho Nadruz, M.A.; Costa, A.F.; Costa, D.P.; Hopkins, M.G.; Leitman, P.M.; Lohmann, L.G.; Lughadha, E.N.; Costa Maia, L.; Martinelli, G.; Menezes, M.; Morim, M.P.; Peixoto, A.L.; Pirani, J.R.; Prado, J.; Queiroz, L.Q.; Souza, S.; Souza, V.C.; Stehmann, J.R.; Sylvestre, L.S.; Walter, B.M.T. \& Zappi, D.C. 2012. New Brazilian floristic list highlights conservation challenges. BioScience 62: 39-45.

Gentry, A.H. 1988. Changes in plant community diversity and floristic composition on environmental and geographical gradients. Annals of the Missouri Botanical Garden 75: 1-34.

Giulietti, A.M.; Harley, R.M.; Queiroz, L.P.; Wanderley, M.G. \& van den Berg, C. 2005. Biodiversidade e conservação das plantas no Brasil. Megadiversidade 1: 52-61.

Gotelli, N.J. \& Colwell, R.K. 2001. Quantifying biodiversity: procedures and pitfalls in the measurement and comparison of species richness. Ecology Letters 4: 379-391.

Gotelli, N.J. \& Entsminger, G.L. 2004. EcoSim: Null models software for ecology. Version 7.72. Montrose, Acquired Intelligence Inc., Kesey-Bear.

Grand, J.; Cummings, M.P.; Rebelo, T.G.; Ricketts, T.H. \& Neel, M.C. 2007. Biased data reduce efficiency and effectiveness of conservation reserve networks. Ecology Letters 10: 364-74.

Harrison, S.; Viers, J.H.; Thorne, J.H. \& Grace, J.B. 2008. Favorable environments and the persistence of naturally rare species. Conservation Letters 1: 65-74.

Hijmans, R.J.; Guarino, L.; Bussink, C.; Mathur, P.; Cruz, M.; Barrentes, I. \& Rojas, E. 2005. DIVA-GIS v.7.4. A geographic information system for the analysis of species distribution data. http://www.diva-gis.org (access on Jan 2013).

Hopkins, M.J.G. 2007. Modelling the known and unknown plant biodiversity of the Amazon Basin. Journal of Biogeography 34: 1400-1411.
Hortal, J.; Lobo, J.M. \& Jiménez-Valverde, A. 2007. Limitations of biodiversity databases: case study on seed-plant diversity in Tenerife, Canary Islands. Conservation Biology 21:853-863.

IBGE - Instituto Brasileiro de Geografia e Estatística. 2012. Manual Técnico da Vegetação Brasileira. Rio de Janeiro, Ministério do Planejamento, Orçamento e Gestão.

Jiménez-Valverde, A. \& Hortal, J. 2003. Las curvas de acumulación de especies y la necesidad de evaluar la calidad de los inventario biológicos. Revista Iberica de Aracnologia 8: 151-161.

Joly, C.A.; Aidar; M.P.M. Klink, C.A.; McGrath, D.G.; Moreira, A.G. Moutinho, P.; Nepstad, D.C.; Oliveira, A.A.; Pott, A.; Rodal, M.J.N. \& Sampaio, E.V.S.B. 1999. Evolution of the Brazilian phytogeography classification systems: implications for biodiversity conservation. Ciência \& Cultura 51: 331-348.

Klein, R.M. 1984. Aspectos dinâmicos da vegetação do Sul do Brasil. Sellowia 36: 5-54.

Laurance, W.F. 2009. Conserving the hottest of the hotspots. Biological Conservation 142: 1137.

Leitão-Filho, H.F. 1994. Diversity of arboreal species in Atlantic Rain Forest. Anais da Academia Brasileira de Ciências 66 (supl. 1): 91-96.

Leite, P.F. 2002. Contribuição ao conhecimento fitoecológico do Sul do Brasil, Ciências \& Ambiente 13(24): 51-73.

Lista de Espécies da Flora do Brasil. 2012. http://floradobrasil.jbrj.gov. br/2012 (access on Dec 2012).

Longino, J.T.; Coddington, J. \& Colwell, R.K. 2002. The ant fauna of a tropical rain forest: estimating species richness three different ways. Ecology 83: 689-702.

Magurran, A. E. 2004. Measuring biological diversity. Oxford, Blackwell Science.

Martinelli, G. 2007. Mountain biodiversity in Brazil. Revista Brasileira de Botânica 30: 587-597.

Martins, F.R. 1991. Estrutura de uma floresta mesófila. Universidade Estadual de Campinas, Campinas.

Myers, N.; Mittermeier, R.A.; Mittermeier, C.G.; Fonseca, G.A.B. \& Kent, J. 2000. Biodiversity hotspots for conservation priorities. Nature 403: $853-858$.

Nimer, E. Clima. 1990. Pp. 151-187. In: IBGE - Fundação Instituto Brasileiro de Geografia e Estatística. Geografia do Brasil: Região Sul. Rio de Janeiro, IBGE.

Oliveira-Filho, A.T. 2009. Classificação das fitofisionomias da América do Sul cisandina tropical e subtropical: proposta de um novo sistema - prático e flexível - ou uma injeção a mais de caos? Rodriguésia 60: 237-258.

Oliveira-Filho, A.T. 2010. TreeAtlan 2.0, flora arbórea da América do Sul cisandina tropical e subtropical: um banco de dados envolvendo biogeografia diversidade e conservação. Universidade Federal de Minas Gerais. http://www.treeatlan.icb.ufmg.br/ (access on Jan 2012).

Oliveira-Filho, A.T. \& Fontes, M.A.L. 2000. Patterns of floristic differentiation among Atlantic forests in south-eastern Brazil, and the influence of climate. Biotropica 32(4b): 793-810.

Pandolfo, C.; Braga, H.J.; Silva Jr, V.P.; Massignam, A.M.; Pereira, E.S. Thomé, V.M.R. \& Valci, F.V. 2002. Atlas climatológico do Estado de Santa Catarina. Florianópolis, Epagri (CD-ROM).

Peres, C.A.; Gardner, T.A.; Barlow, J.; Zuanon, J.; Michalski, F.; Lees, A.C.; Vieira, I.C.G.; Moreira, F.M.S. \& Feeley, K.J. 2010. Biodiversity conservation in human-modified Amazonian Forest landscapes. Biological Conservation 143: 2314-2327.

Pitman, N.C.A.; Terborgh, J.W.; Silman, M.R.; Nuñez, P.V.; Neill, D.A.; Ceron, C.E.; Palacios, W.A. \& Aulestia, M. 2002. A comparison of tree species diversity in two upper Amazonian forests. Ecology 83: 3210-3224.

Ponder, W.F; Carter, G.A.; Flemons, P. \& Chapman, R.R. 2001. Evaluation of museum collection data for use in biodiversity assessment. Conservation Biology 15: 648-657.

Primack, R. B. \& Rodrigues, E. 2001. Biologia da Conservação. Londrina, Editora Rodrigues.

Rabinowitz, D.; Cairns, S. \& Dillon, T. 1986. Seven forms of rarity and their frequency in the flora of the British Isles. Pp. 182-204. In: Soulé, M.E. (Ed.). Conservation biology: The science of scarcity and diversity Sunderland, University of Michigan 
Toward a better understanding of the subtropical Atlantic Forest in the state of Santa Catarina, Brazil:

tree sampling accuracy, tree species richness and frequency of rare tree species

Ribeiro, M.C.; Martensen, A.C.; Metzer, J.P.; Tabarelli, M.; Scarano, F. \& Fortin, M.J. 2011. The Brazilian Atlantic Forest: a shrinking biodiversity hotspot. Pp.405-434. In: Zachos, F.E. \& Habel, J.C. (Eds.). Biodiversity hotspots: distribution and protection of conservation priority areas. New York: Springer.

Rocha, D.S.B. \& Amorim, A.M.A. 2012. Heterogeneidade altitudinal na Floresta Atlântica setentrional: um estudo de caso no sul da Bahia, Brasil. Acta Botanica Brasilica 26: 309-327.

Sampaio, M.B. \& Guarino, E.S.G. 2007. Efeitos do pastoreio de bovinos na estrutura populacional de plantas em fragmentos de Floresta Ombrófila Mista. Revista Árvore 31: 1035-1046.

Santa Catarina. 1986. Atlas de Santa Catarina. Florianópolis, GAPLAN/ SUEGI; Rio de Janeiro, Aerofoto Cruzeiro.

Santos, A.J. 2006. Estimativas de riqueza em espécies. Pp.19-43. In: Cullen, L.; Rudran, R. \& Valladares-Padua, C. (Eds.). Métodos de estudos em Biologia da Conservação \& Manejo da Vida Silvestre. Curitiba, Editora da Universidade Federal do Paraná.

Sastre, P. \& Lobo, J. 2009. Taxonomist survey biases and the unveiling of biodiversity patterns. Biological Conservation 142: 462-467.

Schatz, G.E. 2002. Taxonomy and Herbaria in Service of Plant Conservation: Lessons from Madagascar's Endemic Families. Annals of the Missouri Botanical Garden 89: 145-152.

Schilling, A.C. \& Batista, J.L.F. 2008. Curva de acumulação de espécies e suficiência amostral em florestas tropicais. Revista Brasileira de Botânica 31: 179-187.

Scudeller, V.V.; Martins, F.R. \& Shepherd, G.J. 2001. Distribution and abundance of arboreal species in the atlantic ombrophilous dense forest in Southeastern Brazil. Plant Ecology 152:185-199.

Sobral, M. \& Stehmann, J.R. 2009. An analysis of new angiosperm species discoveries in Brazil (1990-2006). Taxon 58: 227-232.

Stuart, A. \& Ord, J.K. 1991. Kendall's advanced theory of statistics: classical inference and relationships. London, Edward Arnold.

The R Foundation for Statistical Computing. 2012. R: A language and environment for statistical computing. Vienna. http://www.R-project. org/ (access on Dec 2012).
Valente, A.S.M. 2011. Sub-regiões fitogeográficas da Floresta Atlântica entre as bacias dos rio São Francisco e Uruguai baseadas na análise dos padrões de distribuição espacial da flora arbórea e do clima. 2011. 261f. Tese (Doutorado em Engenharia Florestal), Lavras, Universidade Federal de Lavras.

Vibrans, A.C.; McRoberts, R.E.; Moser, P. \& Nicoletti, A. 2013. Using satellite image-based maps and ground inventory data to estimate the remaining Atlantic forest in the Brazilian state of Santa Catarina. Remote Sensing of Environment 130: 87-95.

Vibrans, A.C.; Moser, P.; Lingner, D.V. \& Maçaneiro, J.P. 2012. Análise estatística do IFFSC e estimativas dendrométricas. In: Vibrans, A.C., Sevegnani, L.; Gasper A.L.; Lingner, D.V.. (Org.). Inventário Florístico Florestal de Santa Catarina, Volume 1, Diversidade e Conservação dos remanescentes florestais. Blumenau, Edifurb.

Vibrans, A.C.; Sevegnani, L.; Lingner, D.V.; Gasper, A.L. \& Sabbagh, S. 2010. The Floristic and Forest Inventory of Santa Catarina State (IFFSC): methodological and operational aspects. Brazilian Journal of Forest Research 30: 291-302.

Vibrans, A.C.; Sevegnani, L.; Uhlmann, A.; Schorn, L.A.; Sobral, M.; Gasper, A.L.; Lingner, D.V.; Brogni, E.; Klemz, G.; Godoy, M.B. \& Verdi, M. 2011. Structure of mixed ombrophyllous forest with Araucaria angustifolia (Araucariaceae) under external stress in Southern Brazil. Revista de Biología Tropical 59: 1371-1387.

Walther, B.A. \& Moore, J.L. 2005. The concepts of bias, precision and accuracy, and their use in testing the performance of species richness estimators, with a literature review of estimator performance. Ecography 28: 815-829.

Wickham, H \& Chang, W. 2013. ggplot2: An implementation of the Grammar of Graphics, R package version 0.9.3. http://had.co.nz/ ggplot2/ (access on Jan 2013).

Zafra-Calvo, N.; Rodríguez, M.Á. \& Lobo, J.M. 2010. Discerning the impact of human-mediated factors on biodiversity using bioclimatic envelope models and partial regression techniques. Diversity and Distributions 16: 300-309. 